\title{
Identification and genome analysis of tomato chlorotic spot virus and dsRNA viruses from coinfected vegetables in the Dominican Republic by high-throughput sequencing
}

Reina Teresa Martínez ${ }^{1 \dagger}$, Mariana Martins Severo de Almeida ${ }^{2+}$, Rosalba Rodriguez ${ }^{3}$, Athos Silva de Oliveira ${ }^{2}$, Fernando Lucas Melo ${ }^{2}$ and Renato Oliveira Resende ${ }^{2^{*}}$

\begin{abstract}
The Tomato chlorotic spot virus (TCSV) was first reported in the 1980s, having its occurrence limited to Brazil and Argentina. Due to an apparent mild severity in the past, molecular studies concerning TCSV were neglected. However, TCSV has disseminated over the USA and Caribbean countries. In Dominican Republic TCSV has been recently reported on important cultivated crops such as pepper and beans. In this work, we provide the first complete genome of a TCSV isolate from symptomatic plants in Dominican Republic, which was obtained by high-throughput sequencing. In addition, three dsRNA viruses from different virus families were identified coinfecting these plants Bell pepper endornavirus (BPEV), Southern tomato virus (STV) and Pepper cryptic virus 2 (PCV-2). Phylogenetic analysis showed that the Dominican Republic TCSV isolate has a close relationship with other TCSV isolates and a reassortant isolate between TCSV and Groundnut ringspot virus (GRSV), all found in USA. BPEV, STV and PCV-2 isolates from Dominican Republic were close related to corresponding American isolates. The possible biological implications of these virus-mixed infections are discussed.
\end{abstract}

Keywords: Dominican Republic, Tospovirus, dsRNA viruses, Vegetables, Mixed infection

\section{Background}

Dominican Republic (DR) contains large areas of vegetable production, which bases a significant part of this country economy. Chillies and peppers are amongst the top ten vegetable products exported by DR according to the Observatory of Economic Complexity (OEC), a tool that allows to quickly composing a visual narrative about countries and the products they exchange [1]. Recently, this vegetable production has been threatened by tospoviruses infections, viruses that belong to genus Tospovirus, family Bunyaviridae [2]. While Tomato chlorotic spot virus (TCSV) have caused typical tospovirus symptoms in chili pepper (Capsicum frutescens),

\footnotetext{
* Correspondence: rresende@unb.br

${ }^{\dagger}$ Equal contributors

2Departamento de Biologia Celular, Universidade de Brasília, Brasilia, Brazil Full list of author information is available at the end of the article

long beans (Vigna unguiculata) and tomatoes (Solanum lycopersicum), Tomato spotted wilt virus (TSWV) and TCSV as well have been found in potatoes (S. tuberosum), fresh and processing tomatoes and sweet pepper ( $C$. annuиm) [3-5]. These tospovirus species are notorious for inducing substantial losses on vegetable production around the world [6].

Although frequent reports of new virus species and virus hosts are available, the real diversity of plant viruses has been overlooked for a long period. Only plants with economic importance and presenting compromising symptoms have mostly been surveyed for identification of disease causative agents. With the accessibility of high-throughput sequencing tools, this scenario has changed and viruses, which causing no apparent disease symptoms, have been found in large scales [7-10]. These findings have confirmed the hypothesis that pathogenic 
viruses would rather be an exception than a rule. Some viruses have even been proved to turn plants more tolerant to drought, heat and cold $[11,12]$. Overall, the biological meaning of these mixed infections still has to be elucidated.

In this study sequences covering virus-derived genomes were retrieved from RNA sequencing data of symptomatic vegetables collected in DR. These samples were those previously shown to be positive for TCSV and TSWV [4]. Here we report the first complete genome of a TCSV isolate from DR, in addition to three genomes of dsRNA viruses coinfecting vegetable crops.

\section{Material and methods}

Leaf samples of symptomatic tomato (Solanum lycopersicum), potato (S. tuberosum), long beans (Vigna unguiculata) and chili pepper (Capsicum frutescens) were collected in the province of La Vega, and sweet pepper (C. annuиm) in the province of Monseñor Nouel (Fig. 1). Total RNA isolation was performed using the commercial kit mirVana ${ }^{\text {Tx }}\left(\right.$ Ambion $\left.^{\mathrm{Tx}}\right)$ to improve RNA quality sent for sequencing. Aliquots of each sample were pooled to compose a single sample.

Whole transcriptome shotgun sequencing of the RNA pool was done using an Illumina Hi Seq 2000 platform, which ended up in the production of about 53 million reads. The paired-ends reads were quality-filtered, the adapter sequences were removed, and contigs were assembled de novo using CLC Genomics Workbench version 6.0.3. Contigs covering virus-derived genomes were built by BLASTn and BLASTx searches against the virus reference database available in the National Center for Biotechnology Information (NCBI). The Geneious software was used for further characterization and BLASTx searches.

Specific primers were designed to determine by RTPCR which plants were infected with the viruses found in the deep sequencing analysis (Table 1). The total RNA extracted from tomato, potato, long bean, chilli pepper and sweet pepper were used as template for cDNA synthesis. For first-strand cDNA synthesis, $2 \mu \mathrm{l}$ of each RNA were mixed with $1 \mu$ l specific forward and reverse primer pair $[10 \mu \mathrm{M}], 1 \mu \mathrm{l}$ dNTPs solution $[10 \mathrm{mM}]$ and $8 \mu \mathrm{l}$ RNAse free water under $70{ }^{\circ} \mathrm{C}$ during $5 \mathrm{~min}$, followed by a rapid cooling on ice. Then, it was added per reaction $2 \mu \mathrm{l}[5 \times]$ First Strand ${ }^{\bullet}$ Buffer, $1 \mu \mathrm{l}$ DTT (DL-Dithiothreitol) $[0.1 \mathrm{M}], \quad 0.5 \mu \mathrm{l}$ Moloney Murine Leukemia Virus Reverse Transcriptase (M-MLV RT) (Invitrogen) [200 units./ $\mu \mathrm{l}]$, and water up to a final volume of $20 \mu \mathrm{L}$. The reaction was incubated at $37{ }^{\circ} \mathrm{C}$ for $1 \mathrm{~h}$, followed by a final denaturation at $70{ }^{\circ} \mathrm{C}$ for 15 min. For PCR, Taq Platinum ${ }^{\circ}$ DNA polymerase (Invitrogen) was used as it follows: $1.5 \mu \mathrm{l} \mathrm{MgCl}_{2}$ $[50 \mathrm{Mm}], 2.5 \mu \mathrm{l} 10 \mathrm{X}$ buffer, $0.5 \mu \mathrm{l}$ primer forward $[10 \mu \mathrm{M}], 0.5 \mu \mathrm{l}$ primer reverse $[10 \mu \mathrm{M}], 0.5 \mu \mathrm{l} \mathrm{dNTPs}$ solution $[10 \mathrm{mM}], 0.1 \mu \mathrm{l}$ Taq DNA polymerase, $1 \mu \mathrm{l}$

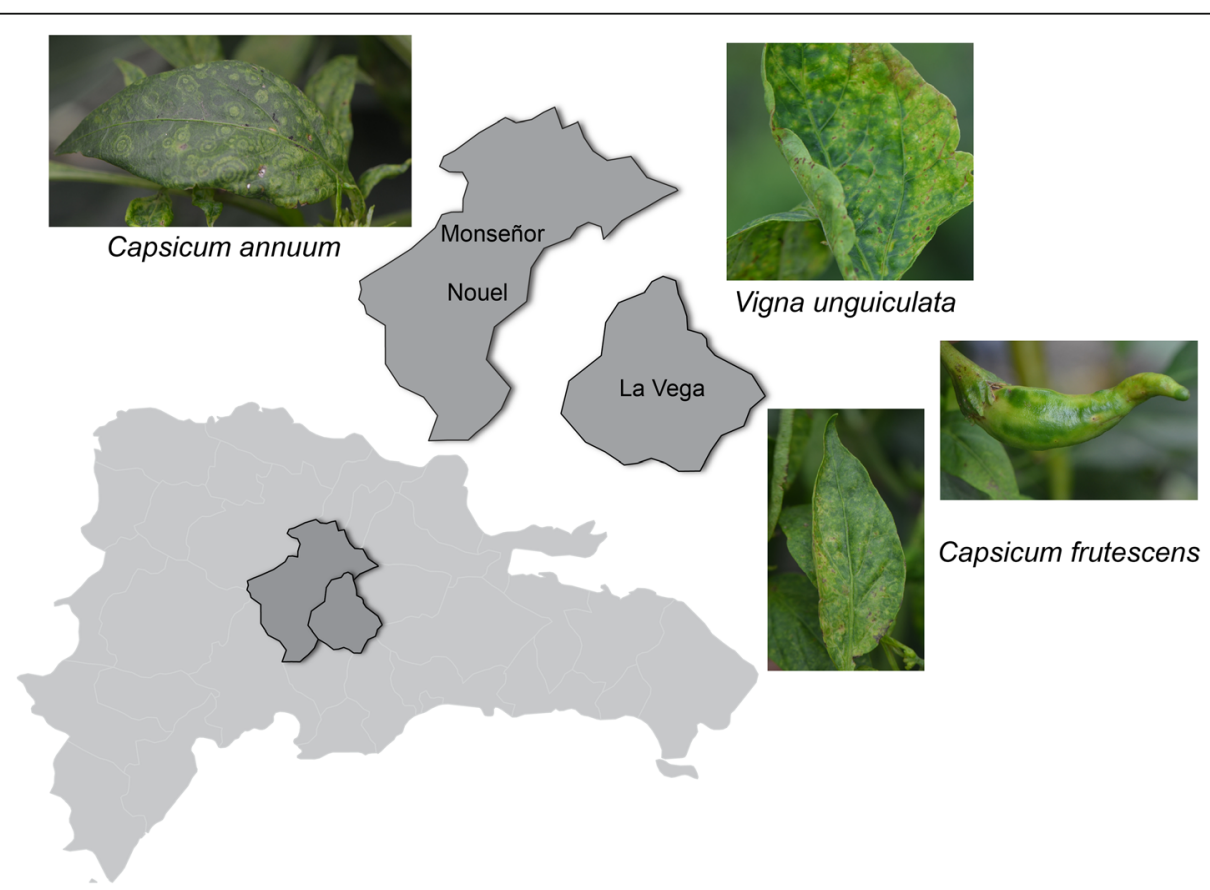

Fig. 1 The Provinces in Dominican Republic where symptomatic samples were collected. Sweet pepper (Capsicum annuum) collected in Monseñor Nouel province showing the typical tospovirus symptom on leaves, the chlorotic rings. Chilli pepper (Capsicum frutescens) from La Vega province showing twisted fruits and chlorotic rings on leaves. Long beans (Vigna unguiculata) collected in La Vega province presenting similar chlorotic and necrotic spots on leaves 
Table 1 Primers used for amplification of virus sequences of symptomatic vegetables from Dominican Republic

\begin{tabular}{|c|c|c|c|}
\hline $\begin{array}{l}\text { Primer } \\
\text { Name }\end{array}$ & Sequence 5' - 3' & $\operatorname{Tm}\left[{ }^{\circ} \mathrm{C}\right]$ & $\begin{array}{l}\text { Anneling } \\
\text { Temperature }\left[{ }^{\circ} \mathrm{C}\right]\end{array}$ \\
\hline$\overline{\text { Amalga }-\mathrm{F}^{\mathrm{a}}}$ & TGG GTA TCG ACA AGC GCT AC & 60.5 & 55 \\
\hline Amalga - $R^{a}$ & ACA TGT CGA AGG CCT CCT TG & 60.5 & 55 \\
\hline Bell - F & CGC TTC GAG CAT AAA AGC CC & 60.5 & 55 \\
\hline Bell - $\mathrm{R}^{\mathrm{b}}$ & TGG CTT GCG CTT TTG TGT AC & 58.4 & 55 \\
\hline Pep70 - F & CAC CCG CAC ACA ATT AAC GG & 60.5 & 55 \\
\hline Pep70 - $R^{c}$ & ACA CAT CT CGG TCC GAC AC & 60.5 & 55 \\
\hline Pep126 - F & ACG CCC CCT ATA ACG CAA AA & 58.4 & 55 \\
\hline Pep126 - R & AAT GTC GCA AGG GCC CAT AA & 58.4 & 55 \\
\hline
\end{tabular}

Melting temperature $(\mathrm{Tm})$ and annealing temperature in $\mathrm{PCR}$ reaction are shown

aprimers to amplify Southern tomato virus (STV)

${ }^{\mathrm{b}}$ Primers to amplity Bell pepper endornavirus (BPEV)

'Primers to amplity Pepper cryptic virus 2 (PCV-2) RNA 1

dPrimers to amplify Pepper cryptic virus 2 (PCV-2) RNA 2

cDNA, and water up to $25 \mu \mathrm{L}$. The amplification program consisted of a primary denaturation at $94{ }^{\circ} \mathrm{C}$ for $2 \mathrm{~min}$, followed by 35 cycles at $94{ }^{\circ} \mathrm{C}$ for $30 \mathrm{~s}, 55^{\circ} \mathrm{C}$ for $30 \mathrm{~s}$ and $72{ }^{\circ} \mathrm{C}$ for $1 \mathrm{~min}$, and one step final extension at $72{ }^{\circ} \mathrm{C}$ for $5 \mathrm{~min}$. PCR products were sent for Sanger sequencing at Macrogen Inc. (South Korea). The sequences were then compared with those deposited in the GenBank database via BLAST.

For phylogenetic analysis, multiple alignments were performed by MUSCLE implemented in Seaview v.4.5.4 and the phylogenetic trees were built by PhyML software [13-15]. Maximum Likelihood was used as the criterion to infer phylogenetic relationships between the isolates. The appropriate nucleotide substitution model was selected by JmodelTest program version 2.1.4 [16]. The visualization and edition of the phylogenetic trees were performed using FigTree v.1.4.1.

\section{Results}

A complete genome of the tospovirus Tomato chlorotic spot virus (TCSV) was assembled (Fig. 2). Tospoviruses are compound by three single stranded-RNAs within spherical particle of $80-120 \mathrm{~nm}$ diameter [2]. The consensus of each genomic segment was deposited under GenBank accession numbers KX463272 [Large (L) segment], KX463273 [Medium (M) segment], and KX463274 [Small (S) segment]. The L segment, which has a negative polarity, encodes a RNA-dependent RNA polymerase of 2874 amino acids (aa). The $M$ segment codes for the viral movement protein (NSm) of 303 aa and for the glycoprotein precursor (GP) of 1134 aa in an ambisense genomic organization. As expected, the same ambisense polarity is observed for the $\mathrm{S}$ segment, which codes for the nucleocapsid $(\mathrm{N})$ protein of 258 aa and a putative RNA silencing suppression protein (NSs) of 469

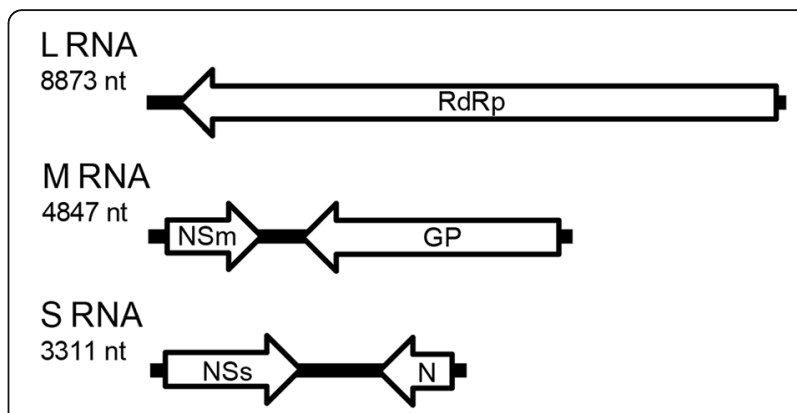

Fig. 2 Genome representation of Tomato chlorotic spot virus (TCSV) isolated from Dominican Republic. The L RNA has a negative polarity with 8873 nucleotides that encodes to the viral RNA polymerase (RdRp). The M RNA has 4847 nucleotides and two ORFs in ambisense orientation that encode to the envelope glycoproteins ( $G n$ and Gc) in the virus- complementary sense and the movement protein (Nsm) in the viral strand. The S RNA with 3311 nucleotides is ambisense as well. The viral strand encodes to the non-structural protein (Nss) and the complementary strand the nucleocapsid protein (N). The expected sizes of TCSV-encoded proteins are indicated. The consensus of each genomic segment was deposited under GenBank accession numbers KX463272 [Large (L) segment], KX463273 [Medium (M) segment], and KX463274 [Small (S) segment]

aa (Fig. 2). Pairwise comparisons of the N, NSs and RdRp protein sequences showed that TCSV-DR is most closely related to the TCSV isolates reported in cultivated and ornamental plants $[17,18]$. The NSm and the glycoprotein precursor protein sequences analysis revealed TCSV-DR closest to the unique reassortant isolate formed between TCSV and GRSV $\left(\mathrm{S}_{\mathrm{GRSV}}, \mathrm{M}_{\mathrm{TCSV}}\right.$ and $\mathrm{L}_{\mathrm{GRSV}}$ ) (Fig. 3) [19].

The sequencing also revealed RNA genomes of dsRNA viruses from three different genera, apart from the complete genome of TCSV and partial sequences of TSWV. All virus sequences matched with species previously reported infecting crops (Table 2).

A contig corresponding to a complete sequence of a Bell pepper endornavirus (BPEV-DR) isolate (Family Endornaviridae) was found and traced back in chilli pepper (C. frutescens) (GenBank accession no. KX525267). The viruses from family Endornaviridae present a dsRNA genome that range in length from about $14 \mathrm{kbp}$ to $17.6 \mathrm{kbp}$ [20]. The genome of BPEV-DR consists of 14,790 nucleotides in size, coding for a single open reading frame (ORF) starting at nucleotide (nt) 23 and ending at the nt 14,677, which could encode for a polyprotein of 4884 amino acids (aa). The putative BPEV-DR protein product shared 92-99\% similarity with the single ORF of BPEV already reported. Multiple alignment with complete endornaviruses sequences avaiable on the GenBank database showed that BPEV-DR presents $87 \%-99 \%$ nucleotide identity with BPEV isolates found in America, Asia and Middle East [7, 10, 21-23, 24]. Phylogenetic analysis using whole genome showed 


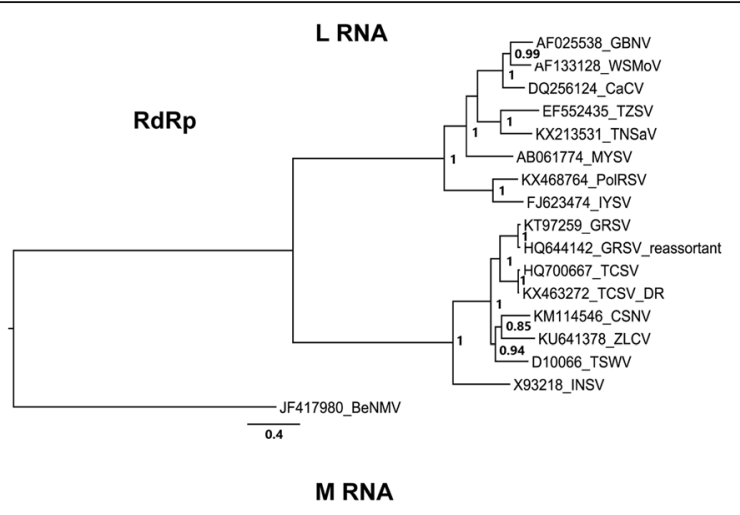

GnGc

NSm

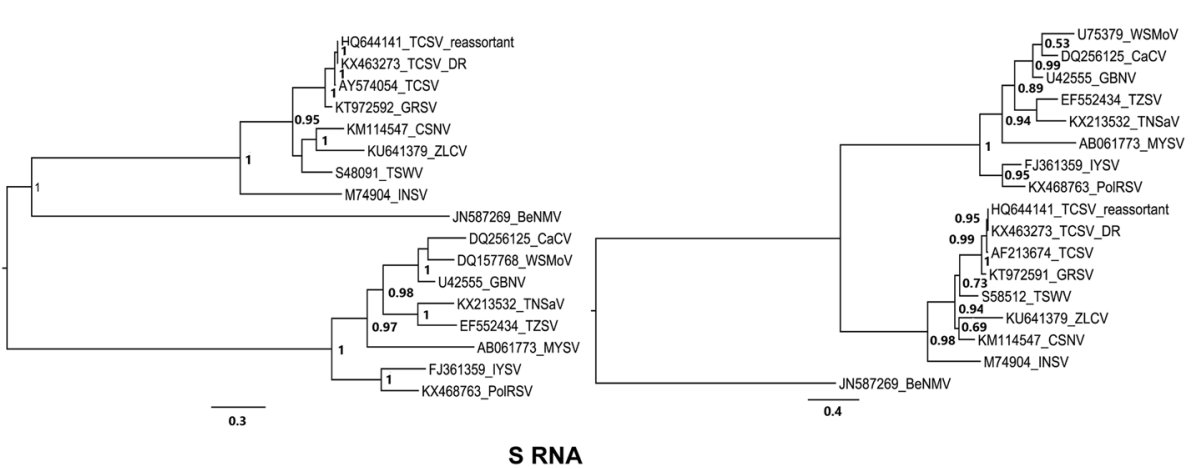

S RNA

N

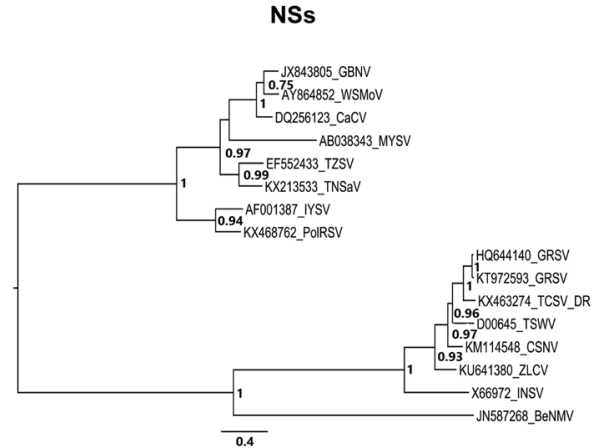

Fig. 3 Tospovirus phylogeny. Trees were based on amino acid sequences of the structural proteins RNA-dependent RNA polymerase (RdRp), the nucleocapsid (N) and the glycoprotein ( $\mathrm{GnGc}$ ) and the non-structural movement (Nsm) and the silence suppressor (Nss) proteins. The species included in the phylogenetic analysis were Bean necrotic spot virus (BeNMV), Capsicum chlorosis virus (CaCV), Groundnut bud necrosis virus (GBNV), Groundnut ringspot virus (GRSV), Groundnut ringspot virus/Tomato chlorotic spot virus (reassortant) (GR/TC), Chrysanthemum stem necrosis virus (CSNV), Impatiens necrotic spot virus (INSV), Iris yellow spot virus (IYSV), Melon yellow spot virus (MYSV), Polygonum ringspot virus (PoIRSV), Tomato chlorotic spot virus (TCSV), Tomato necrotic spot-associated virus (TNSaV), Tomato spotted wilt virus (TSWW), Tomato zonate spot virus (TZSV), Watermelon silver mottle virus (WSMoV) and Zucchini lethal chlorosis virus (ZLCV). The GenBank accession numbers of the sequences are shown in the trees. Nodes values with posterior probability $>50 \%$ are shown. Protein sequences were used to verify the phylogenetic relationship of the Tomato chlorotic spot virus (TCSV) isolate reported in Dominican Republic (GenBank accession numbers KX463272 [L RNA], KX463273 [M RNA], KX463274 [S RNA]). The proteins encoded at S and L RNAs clustered with the TCSV isolate already reported (GenBank accession numbers AF282982 [S RNA] and HQ700667 [L RNA]), while those encoded at M RNA are closer to the hybrid North American TCSV/GRSV (reassortant) isolate (GenBank accession number HQ644141)

that BPEV-DR clustered in a separate group with the American isolate Maor (GenBank accession no. KP455654) and a Canadian isolate (GenBank accession no. KT149366) (Fig. 4).

A Southern tomato virus (STV-DR) isolate was found infecting tomato (GenBank accession no. KX525266).
The STV is classified within the genus Amalgavirus (family Amalgaviridae), usually presenting a dsRNA genome of about $3.5 \mathrm{~kb}$ that encodes two overlapping ORFs [2, 25]. The STV-DR genome has $3.425 \mathrm{~kb}$ and shares more than 99\% nucleotide identity with other STV isolates from America, Asia and Europe [25, 26]. 
Table 2 Viruses species sequenced from the RNA pool and traced back in infected vegetables

\begin{tabular}{|c|c|c|c|c|}
\hline Virus Species & Virus Family & DR Host ${ }^{a}$ & $\begin{array}{l}\text { Acession } \\
\text { Number }\end{array}$ & $\begin{array}{l}\text { Genome } \\
\text { Type }\end{array}$ \\
\hline $\begin{array}{l}\text { Bell pepper } \\
\text { endornavirus } \\
\text { (BPEV) }\end{array}$ & Endornaviridae & Sweet Pepper & KX525267 & dsRNA \\
\hline \multirow{2}{*}{$\begin{array}{l}\text { Pepper cryptic } \\
\text { virus } 2 \text { (PCV-2) } \\
\text { (bipartite) }\end{array}$} & \multirow[t]{2}{*}{ Partitiviridae } & \multirow[t]{2}{*}{ Chilli Pepper } & $\begin{array}{l}\text { KX525268 } \\
\text { (RNA1) }\end{array}$ & \multirow[t]{2}{*}{ dsRNA } \\
\hline & & & $\begin{array}{l}\text { KX525269 } \\
\text { (RNA 2) }\end{array}$ & \\
\hline $\begin{array}{l}\text { Southern tomato } \\
\text { virus (STV) }\end{array}$ & Amalgaviridae & Tomato & KX525266 & dsRNA \\
\hline \multirow{3}{*}{$\begin{array}{l}\text { Tomato chlorotic } \\
\text { spot virus (TCSV) } \\
\text { (tripartite) }\end{array}$} & \multirow[t]{3}{*}{ Bunyaviridae } & \multirow[t]{3}{*}{$\begin{array}{l}\text { Chilli Pepper; } \\
\text { Long Beans }\end{array}$} & $\begin{array}{l}\text { KX525272 } \\
\text { (L RNA) }\end{array}$ & \multirow[t]{3}{*}{ ssRNA } \\
\hline & & & $\begin{array}{l}\text { KX525273 } \\
\text { (M RNA) }\end{array}$ & \\
\hline & & & $\begin{array}{l}\text { KX525274 } \\
\text { (S RNA) }\end{array}$ & \\
\hline
\end{tabular}

${ }^{a}$ DR-Host - Comercial vetables coinfected by tospovirus and other dsRNA viruses in Dominican Republic

Analysis of the STV-DR genome showed the presence of the two overlapping ORFs. The ORF 1 encodes a 377 aa putative coat protein, initiated at nt 126 and ending at nt 1257. Another ORF encoding a protein of 762 aa starts at nt 1027 and ending at nt 3315 and presents homology with RNA-dependent RNA polymerase

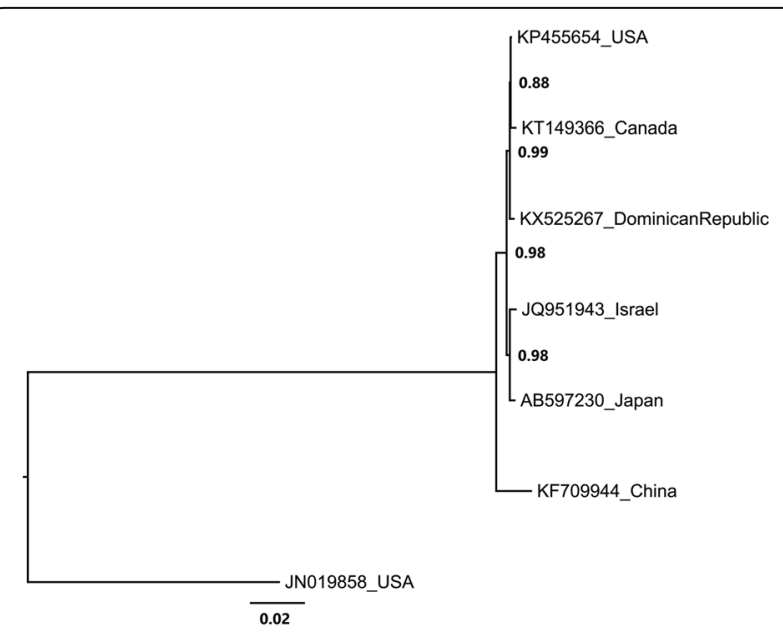

Fig. 4 Bell pepper endornavirus (BPEV) phylogeny. The tree based on nucleotide sequences of BPEV available on GenBank. Complete nucleotide sequences of BPEV isolates deposited in GenBank were used to analyse the phylogenetic relationship of the isolate found in Dominican Republic (GenBank accession number KX525267). The isolates are represented in the tree by the accessions numbers of the sequences and the collection point. Nodes values with posterior probability $>50 \%$ are shown. The Dominican Republic isolate is shown to be more phylogenetic related to others Americans isolates, as the Canadian (GenBank accession number KT149366) and the North American (GenBank accession number KP456554)
(RdRp) sequences available on the GenBank database. Both ORFs feature over 99\% identity with other STV isolates previously reported. Phylogenetic analysis performed with complete STV genomes available on GenBank showed that STV-DR isolate establishes relationship with Americans and Asiatic isolates as well. Due to the low genetic variability, the exact phylogenetic relationship of the Dominican Republic isolate with other STV isolates could not be defined (Fig. 5).

A Pepper cryptic virus 2 (PCV-2-DR) isolate was identified in sweet pepper (Capsicum annuum cv. Magali). The PCV-2 belongs to the genus Deltapartitivirus (family Partitiviridae), presenting a bipartite dsRNA genome [27]. The RNA 1 of the PCV-2-DR has $1.586 \mathrm{~kb}$ in size (GenBank accession no. KX525268), while the RNA 2 has $1.534 \mathrm{~kb}$ (GenBank accession no. KX525269). The PCV-2-DR RNA 1 presents more than 95\% identity with other PCV-2 isolates. PCV-2-DR RNA 2 has $98 \%$ identity with other PCV-2 isolates. RNA 1 encodes for a RdRp protein of 478 aa, which is at least $96 \%$ identity to RdRp from PCV-2 already reported. It starts at nt 86 until nt 1522 . In the RNA 2 there is an ORF coding for a putative coat protein of 430 aa, which begins in nt 9 and ends in nt 1301. Phylogenetic showed that PCV-2-DR RNAs clustered with PCV-2 isolates from USA (GenBank accession numbers JN117278 [RNA1] and JN117279 [RNA2]), South Korea (GenBank accession numbers LC195294 [RNA1] and LC195295 [RNA2]) and China (GenBank accession numbers KX905077 [RNA1] and KX905078 [RNA2]) (Fig. 6).

\section{Discussion}

In this paper, we present the detection of viruses in symptomatic plants from important crops in Dominican Republic by deep sequencing. Viruses from four different genera were identified in a RNA pool isolated from tomato, potato, chilli pepper, sweet pepper and long beans samples. RT-PCR reactions confirmed the presence of those viruses in each plant host. A PCV-2 isolate (PCV2-DR) was identified in sweet pepper, coexisting with the tospovirus TSWV. A STV isolate (STV-DR) was mixinfecting tomato together with TSWV as well. A BPEV isolate (BPEV-DR) was co-infecting chilli pepper together with TCSV.

The endornaviruses do not show significant nucleotide identity between species, which evidences host/virus coevolution [21, 28]. BPEV has been described infecting Capsicum spp. species [7, 10, 21, 23]. BPEV-DR was identified in Capsicum frutescens plants showing chlorotic and necrotic spots, mild curling on leafs and warped fruits (Fig. 1). BPEV infections have not been associated with expressive symptoms. Even when it occurs in coinfection with other viruses, no phenotypic changes have been usually observed, apart from those expected from 


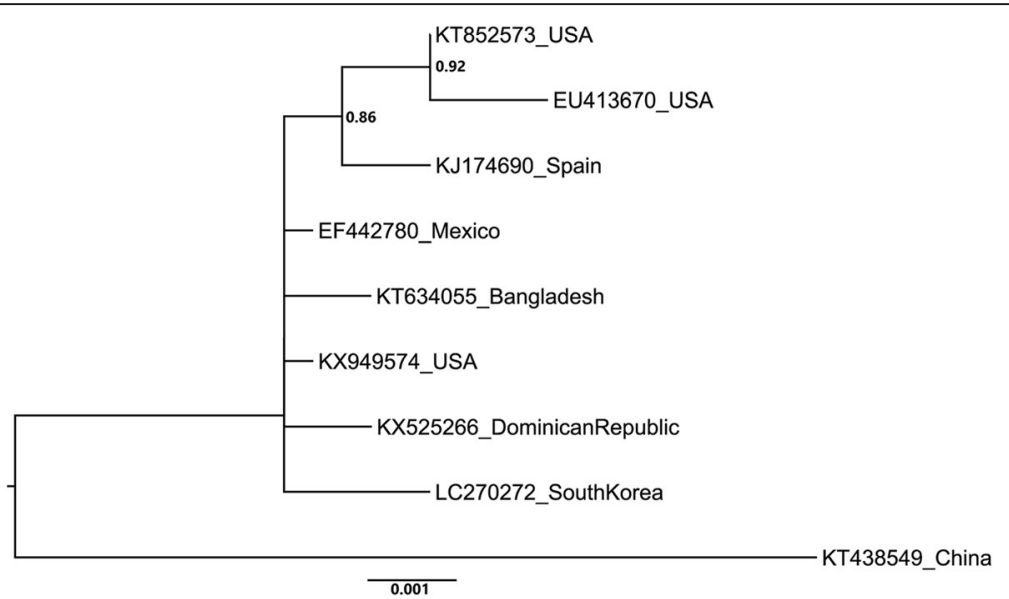

Fig. 5 Southern tomato virus (STV) phylogeny. The tree was based on nucleotide sequences of STV available on GenBank. Complete nucleotide sequences of STV isolates deposited in GenBank were used to analyse the phylogenetic relationship of the isolate found in Dominican Republic (GenBank accession number KX525266). The isolates are represented in the tree by the accessions numbers of the sequences and the collection point. Nodes values with posterior probability $>50 \%$ are shown. Due to the low genetic variability, the exact phylogenetic relationship of the Dominican Republic isolate with other STV isolates could not be define. It establishes relationship with Americans and Asiatic isolates as well

more symptomatic virus, as TSWV, Potato virus $Y$ (PVY) and Pepper mild mottle virus (PMMoV) [21]. BPEV-DR is more phylogenetically related to North American isolates, which seem to cause soft symptoms as chlorosis and mild crinkling on young leaves [23]. The symptoms observed in chilli peppers (C. frutescens) from Dominican Republic do not seem to be associated with one factor only, since there are more than the usual chlorotic rings induced by tospoviruses in the leaves. It might be possible that the symptoms are due to the mixed infection and/or a virussynergistic effect between BPEV and TCSV.
PCV-2 has been basically detected in cultivars of Capsicum аппиит in mixed or single infections, being isolated from symptomatic and asymptomatic plants $[29,30]$. PCV-2-DR was isolated from symptomatic sweet pepper plants (Fig. 1), which were concomitantly infected with TSWV. PCV-2 has been reported co-infecting plants with Cuncumber mosaic virus (CMV), TSWV, PVY and PMMoV. Single infection of PCV-2 has not caused any visible symptoms [21, 29-33]. The symptoms observed in sweet peppers from Dominican Republic seem to be solely induced by tospoviruses (Fig. 1).
RNA 1

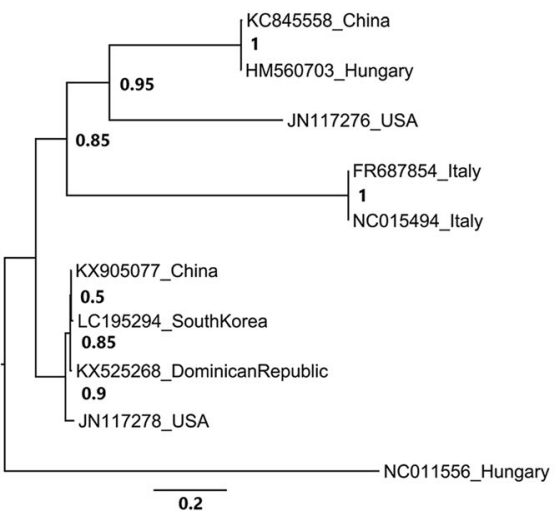

\section{RNA 2}

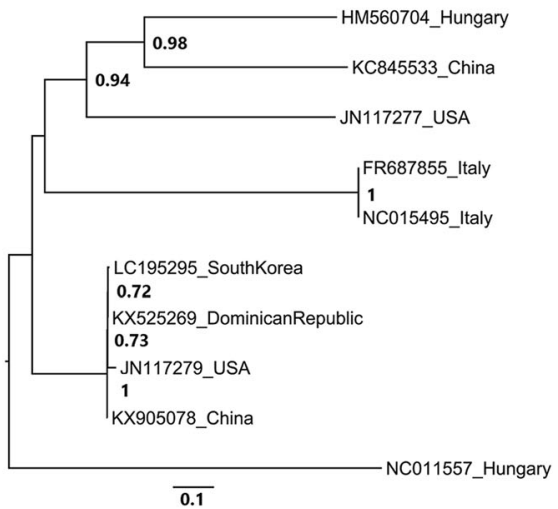

Fig. 6 Pepper cryptic virus 2 (PCV-2) phylogeny. Tree based on complete nucleotide sequences of deltapartitivirus species deposited on GenBank. The isolates are represented in the tree by the accessions numbers of the sequences and the collection point Nodes values with posterior probability $>50 \%$ are shown. Sequences were used to analyse the phylogenetic relationship of PCV-2 isolated in Dominican Republic (GenBank accession number KX525268 [RNA1] and KX525269 [RNA2]). Both RNAs of Dominican Republic PCV-2 isolate (GenBank accession number KX525268 [RNA1] and KX525269 [RNA2]) are more phylogenetic related to an American isolate and Asian isolates from China (GenBank accession number KX905078) and South Korea (GenBank accession number LC195295) 
STV has been reported infecting different tomatoes cultivars worldwide $[25,26,34,35]$. This virus shares biological similarities with other viruses. STV has been associated with a specific phenotype in tomato plants, known as the 'tomato yellow stunt' disease [25]. As observed in Dominican Republic samples, STV usually co-exist with viruses from other taxonomical groups like Tobbaco mosaic virus (TMV), PVY, TSWV, Pepino mosaic virus (PepMV), Tomato leaf curl virus (TYLCV), CMV and Tomato chlorosis virus (ToCV) [25, 26, 34-38]. Besides that, STV dsRNA has been isolated from both symptomatic and asymptomatic plants, which leads to the question if STV is able to cause any symptom in tomatoes $[25,26]$. In Dominican Republic samples STV was detected along with TSWV however, it is not clear if both viruses are responsible for the symptoms observed in the field.

Tomato chlorotic spot virus (TCSV) was first reported in tomatoes plants from Brazil in the 1980s [39, 40]. Until recently, TCSV occurrence had been restricted to Argentinean counties and few Brazilian states, without compromising agricultural production [41-45]. However, during the last 4 years, severe TCSV infections have been reported in Caribbean countries (Dominican Republic, Costa Rica and Haiti) and in the south and southeast of the USA [4, 5, 17, 46-49]. Beans, chilli peppers and tomatoes were the first crops affected by TCSV in Dominican Republic $[4,5]$. The tospovirus phylogenetic analysis revealed that the TCSV-DR clustered with a TCSV isolate previously reported, when the $\mathrm{S}$ and $\mathrm{L}$ RNAs are considered, and with the only tospovirus reassortant isolate for RNA M-coded proteins (Fig. 5). The reassortant isolate is a hybrid that has the $\mathrm{S}$ and L RNA from GRSV and the M RNA from TCSV [19]. Few years later TCSV has been discovered in USA, it was reported in Central America for the first time [4, 5, 17]. This recent TCSV appearance in Dominican Republic may be due to the plant material trade in the Americas, since imported plants, plants cuttings, seeds and other plant propagative material generally pose the highest risk for introducing foreign plant pests and diseases [50]. Besides that, the World Trade Organization (WTO) forbids the use quarantine rules to protect their markets. This rules allows countries and/or continents, to execute their own regulatory policies, with the commitment that there are not protectionism [51]. Among tospoviruses that infect important crops, TCSV is commonly find in ornamental plants as well, which favours it spread, since these ornamentals species have a high potential to transfer pests and diseases through different geographic regions [52]. According to the Observatory of Economic Complexity (OEC) [1], chilli peppers and others Capsicum species are one of the main crop product traded by Dominican Republic. As solanaceous plants, which have been important tospoviruses hosts, these crops became an important virus source.

The recent Dominican Republic (DR) scenario represents an important model to study plant virus interaction and evolution in a restricted area, since multiple plant viruses infections seem to be a common feature and not the exception.

\section{Conclusions}

This work provided the first complete genome of a TCSV isolate from symptomatic plants in Dominican Republic, which was obtained by high-throughput sequencing. Coinfections with three viruses from different virus families were also identified, Bell pepper endornavirus (BPEV), Southern tomato virus (STV) and Pepper cryptic virus 2 (PCV-2). The NGS and PCR data showed viruses that have not been described before in DR coexisting in the same host with other important plant viruses, recently reported in the country, as the tospoviruses TCSV and TSWV. The nature and the implications of such interactions are still unknown.

\section{Abbreviations}

BeNMV: Bean necrotic spot virus; BPEV: Bell pepper endornavirus; BPEV-DR: Bell pepper endornavirus isolated from Dominican Republic; CaCV: Capsicum chlorosis virus; CMV: Cuncumber mosaic virus; CSNV: Chrysanthemum stem necrosis virus; DR: Dominican Republic; GBNV: Groundnut bud necrosis virus; GP: Tospovirus glycoprotein; GR/TC: Groundnut ringspot virus/Tomato

chlorotic spot virus (reassortant); GRSV: Groundnut ringspot virus; INSV: Impatiens necrotic spot virus; IYSV: Iris yellow spot virus; L

RNA: Tospovirus large RNA segment; LGRSv: L RNA from Groundnut ringspot virus; M RNA: Tospovirus medium RNA segment; MTcsv: M RNA from Tomato chlorotic spot virus; MYSV: Melon yellow spot virus; N: Tospovirus nucleocapsid protein; NCBI: National Center for Biotechnology Information; NSm: Tospovirus movement protein; NSs: Tospovirus silencing suppression protein; OEC: Observatory of Economic Complexity; ORF: Open reading frame; PCV-2: Pepper cryptic virus 2; PCV-2-DR: Pepper cryptic virus 2 isolated from Dominican Republic; PepMV: Pepino mosaic virus; PMMoV: Pepper mild mottle virus; PolRSV: Polygonum ringspot virus; PVY: Potato virus Y; RdRp: RNAdependent RNA polymerase; RNA 1: Pepper cryptic virus 2 first RNA segment; RNA 2: Pepper cryptic virus 2 s RNA segment; S RNA: Tospovirus small RNA segment; $\mathrm{S}_{\text {GRSV: }}$ S RNA from Groundnut ringspot virus; STV: Southern tomato virus; STV-DR: Southern tomato virus isolated from Dominican Republic; TCSV: Tomato chlorotic spot virus; TCSV-DR: Tomato chlorotic spot virus isolated from Dominican Republic; TMV: Tobbaco mosaic virus;

TNSaV: Tomato necrotic spot-associated virus; ToCV: Tomato chlorosis virus; TSWV: Tomato spotted wilt virus; TYLCV: Tomato leaf curl virus; TZSV: Tomato zonate spot virus; WSMoV: Watermelon silver mottle virus; WTO: World Trade Organization; ZLCV: Zucchini lethal chlorosis virus

\section{Acknowledgements}

Not applicable.

\section{Funding}

This work was supported by grant of Fondo Nacional de Innovación y Desarrollo Científico y Tecnológico (FONDOCYT) from Dominican Republic and grants from CNPq (Conselho Nacional de Desenvolvimento Científico e Tecnológico), Capes (Conselho de Aperfeiçoamento de Pessoal de Nível Superior) and FAP-DF (Fundação de Apoio à Pesquisa do Distrito Federal) from Brazil.

\section{Availability of data and materials}

All DNA sequences have been submitted in genbank (http:// www.ncbi.n/m.nih.gov/genbank/) under the following accession numbers: KX525267, KX525268, KX525269, KX525266, KX463272, KX463273, KX463274. 


\section{Authors' contributions}

ROR, FLM, RTM designed the study, MMSA, ASO and RR performed the research, FLM analysed data and MMSA and ASO wrote the paper. All authors read and approved the final manuscript.

\section{Ethics approval and consent to participate}

Not applicable.

\section{Consent for publication}

Not applicable.

\section{Competing interests}

The authors declare that they have no conflict of interest.

\section{Publisher's Note}

Springer Nature remains neutral with regard to jurisdictional claims in published maps and institutional affiliations.

\section{Author details \\ 'Universidad Autónoma de Santo Domingo-UASD and Instituto Dominicano de Investigaciones Agropecuarias y Florestales - IDIAF, Santo Domingo, Dominican Republic. ${ }^{2}$ Departamento de Biologia Celular, Universidade de Brasília, Brasilia, Brazil. ${ }^{3}$ Universidad Autónoma de Santo Domingo-UASD, Santo Domingo, Dominican Republic.}

\section{Received: 22 October 2017 Accepted: 12 January 2018}

\section{Published online: 26 January 2018}

\section{References}

1. Simoes AJG, Hidalgo CA. The economic complexity observatory: an analytical tool for understanding the dynamics of economic development. Workshops at The Twenty-Fifth AAAl Conference on Artificial Intelligence. 2011;2011:29-42.

2. Plyusnin A, Beaty BJ, Elliot RM, Goldbach R, Kormelink R, Lundkvist $\AA$, Schmaljohn CS, Tesh RB. Family Bunyaviridae. In: King AMQ, Adams MJ, Carstens $E B$, Lefkowitz EJ, editors. Virus taxonomy: ninth report of the international committee on taxonomy of viruses. San Diego: Elsevier; 2012. p. 725-41.

3. Martínez RT, Poojari S, Tolin SA, Cayetano X, Naidu RA. First report of Tomato spotted wilt virus in peppers and tomato in the Dominican Republic. Plant Dis. 2013; https://doi.org/10.1094/PDIS-06-13-0617-PDN.

4. Almeida MMS, Orílio AF, Melo FL, Rodriguez R, Feliz A, Cayetano X, Martínez RT, Resende RO. The first report of Tomato chlorotic spot virus (TCSV) infecting long beans and chili peppers in the Dominican Republic. Plant Dis. 2014,https://doi.org/10.1094/PDIS-04-14-0348-PDN.

5. Batuman O, Rojas MR, Almanzar A, Gilbertson RL. First report of Tomato chlorotic spot virus in processing tomatoes in the Dominican Republic. Plant Dis. 2013; https://doi.org/10.1094/PDIS-07-13-0685-PDN.

6. Pappu HR, Jones RAC, Jain RK. Global status of tospovirus epidemics in diverse cropping systems: successes achieved and challenges ahead. Virus Res. 2009;141:219-36.

7. Sela N, Luria N, Dombrovsky A. Genome assembly of bell pepper endornavirus from small RNA. J Virol. 2012; https://doi.org/10.1128/JVI. 00983-12.

8. Jo Y, Choi H, Cho WK. De novo assembly of a bell pepper endornavirus genome sequence using RNA sequencing data. Genome Announc. 2015; https://doi.org/10.1128/genomeA.00061-15.

9. Alcala-Briseno Rl, Coskan S, Londoño MA, Polston JE. Genome sequence of Southern tomato virus in asymptomatic tomato 'sweet hearts'. Genome Announc. 2017; https://doi.org/10.1128/genomeA.01374-16.

10. Jo Y, Choi H, Yoon JY, Choi SK, Cho WK. In silico identification of Bell pepper endornavirus from pepper transcriptomes and their phylogenetic and recombination analyses. Gene. 2016;575:712-7.

11. Roossinck MJ. Plant virus ecology. PLoS Pathog. 2013; https://doi.org/10. 1371/journal.ppat.1003304.

12. Xu P, Chen F, Mannas JP, Feldman T, Sumner LW, Roossinck MJ. Virus infection improves drought tolerance. New Phytol. 2008;180:911-21.

13. Edgar RC. MUSCLE: multiple sequence alignment with high accuracy and high throughput. Nucleic Acids Res. 2004;32:1792-7.

14. Guindon S, Gascuel O. A simple, fast, and accurate algorithm to estimate large phylogenies by maximum likelihood. Syst Biol. 2003;52:696-704.
15. Gouy M, Guindon S, Gascuel O. SeaView version 4: a multiplatform graphical user interface for sequence alignment and phylogenetic tree building. Mol Biol Evol. 2010;27:221-4.

16. Darriba D, Taboada GL, Doallo R, Posada D. jModelTest 2: more models, new heuristics and parallel computing. Nat Methods. 2012; https://doi.org/ 10.1038/nmeth.2109.

17. Londoño A, Capobianco H, Zhang S, Polston JE. First record of Tomato chlorotic spot virus in the USA. Tropi Plant Pathol. 2012;37:333-8.

18. Warfield CY, Clemens K, Adkins S. First report of Tomato chlorotic spot virus on annual vinca (Catharanthus roseus) in the United States. Plant Dis. 2015; https://doi.org/10.1094/PDIS-12-14-1269-PDN.

19. Webster CG, Reitz SR, Perry KL, Adkins S. A natural M RNA reassortant arising from two species of plant- and insect-infecting bunyaviruses and comparison of its sequence and biological properties to parental species. Virol. 2011;413:216-25.

20. Fukuhara T, Gibbs MJ. Family Endornaviridae. In: King AMQ, Adams MJ, Carstens $E B$, Lefkowitz EJ, editors. Virus taxonomy: ninth report of the international committee on taxonomy of viruses. San Diego: Elsevier; 2012. p. 519-21.

21. Okada R, Kiyota E, Sabanadzovic S, Moriyama H, Fukuhara T, Saha P, Rossinck MJ, Severin A, Valverde RA. Bell pepper endornavirus: molecular and biological properties, and occurrence in the genus capsicum. J. Gen. Virol. 2011;92:2664-73

22. Kwon SJ, Tan SH, Vidalakis G. Complete nucleotide sequence and genome organization of an endornavirus from bottle gourd (Lagenaria siceraria) in California. USA Virus Genes. 2014;49:163-8.

23. Chen B, Bernards M, Wang A. Complete genome sequence of a bell pepper endornavirus isolate from Canada. Genome Announc. 2015; https://doi.org/ 10.1128/genomeA.00905-15.

24. Boccardo G, Lisa V, Luisoni E, Milne RG. Cryptic plant viruses. Adv Virus Res. 1987;32:171-214.

25. Sabanadzovic S, Valverde RA, Brown JK, Martin RR, Tzanetakis IE. Southern tomato virus: the link between the families Totiviridae and Partitiviridae. Virus Res. 2009;140:130-7.

26. Padmanabhan C, Zheng Y, Li R, Sun SE, Zhang D, Liu Y, Fei Z, Ling KS. Complete genome sequence of Southern tomato virus naturally infecting tomatoes in Bangladesh. Genome Announc. 2015; https://doi.org/10.1128/genomeA.01226-15.

27. Nibert ML, Ghabrial SA, Maiss E, Lesker T, Vainio EJ, Jiang D, Suzuki N. Taxonomic reorganization of family Partitiviridae and other recent progress in partitivirus research. Virus Res. 2014;188:128-41.

28. Valverde RA, Gutierrez DL. Transmission of a dsRNA in bell pepper and evidence that it consists of the genome of an endornavirus. Virus Genes. 2007;35:399-403.

29. Valverde RA, Gutierrez DL. Molecular and biological properties of a putative partitivirus from jalapeño pepper (Capsicum annuum L.). Rev Mexic fitopatol. 2008;26:1-6.

30. Sabanadzovic S, Valverde RA. Properties and detection of two cryptoviruses from pepper (Capsicum annum). Virus Genes. 2011;43:307-12.

31. Valverde RA, Nameth ST, Jordan RL. Indigenous double-stranded RNA from pepper (Capsicum annuum). Plant Sci. 1990;74:255-8.

32. Saritha RK, Jain P, Baranwal VK, Jain RK, Srivastava A, Kalia P. First report of Pepper cryptic virus 2 in chilli (Capsicum annuum) in India. Virus Dis. 2016;27:327-8.

33. Sun M, Jing CC, Wu GT, Sun XC, Liu Y, Qing L. First report of Pepper cryptic virus 2 infecting pepper in China. J Plant Pathol. 2017; http://sipav.org/main/ jpp/index.php/jpp/article/view/3808.

34. Candresse T, Marais A, Faure C. First report of Southern tomato virus on tomatoes in Southwest France. Plant Dis. 2013; https://doi.org/10.1094/PDIS01-13-0017-PDN.

35. Verbeek M, Dullemans AM, Espino A, Botella M, Alfaro-Fernández A, Font MI. First report of southern tomato virus in tomato in the Canary Islands, Spain. J Plant Pathol. 2015; http://sipav.org/main/jpp/index.php/jpp/article/view/ 3356.

36. Lockhart BE, Menke J, Dahal G, Olszewski NE. Characterization and genomic analysis of tobacco vein clearing virus, a plant pararetrovirus that is transmitted vertically and related to sequences integrated in the host genome. J Gen, Virol. 2000;81:1579-85.

37. Horiuchi $\mathrm{H}$, Fukuhara T. Putative replication intermediates in Endornavirus, a novel genus of plant dsRNA viruses. Virus Genes. 2004;29:365-75.

38. Staginnus $\mathrm{C}$, Gregor W, Mette MF, Teo CH, Borroto-Fernández EG, Machado MLC, Matzke M, Schwarzacher T. Endogenous pararetroviral sequences in tomato (Solanum lycopersicum) and related species. BMC Plant Biol. 2007; https://doi.org/10.1186/1471-2229-7-24. 
39. Ávila AC, Huguenot C, Resende RO, Kitajima EW, Goldbach RW, Peters D. Serological differentiation of 20 isolates of tomato spotted wilt virus. J. Gen. Virol. 1990;71:2801-7.

40. Ávila AC, Haan P, Kormelink R, Resende RO, Goldbach RW, Peters D. Classification of tospoviruses based on phylogeny of nucleoprotein gene sequences. J Gen Virol. 1993;74:153-9.

41. Dewey RA, Semorile LC, Grau O, Crisci JV. Cladistic analysis of Tospovirus using molecular characters. Mol Phylogenet Evol. 1997;8:11-32.

42. Nagata T, Ávila AC, Tavares PCTM, Barbosa CJ, Juliatti FC, Kitajima EW. Occurrence of different tospoviruses in six states of Brazil. Fitopatol Bras. 1990;20:90-4.

43. Ávila AC, Lima MF, Resende RO, Pozzer L, Ferraz E, Maranhão EAA, Candeia JA, Costa ND. Identificação de tospovírus em hortaliças no Submédio São Francisco utilizando DAS-ELISA e DOT-ELISA. Fitopatol Bras. 1996;21:503-8.

44. Lima MF, Ávila AC, Resende RO, Nagata T. Levantamento e identificação de espécies de Tospovirus em tomateiro e pimentão no Submédio do Vale São Francisco e no Distrito Federal. Summa Phytopathol. 2000;26:205-10.

45. Eiras M, Costa IFD, Chaves ALR, Colariccio A, Harakava R, Tanaka FAO, Garcêz RM, Silva LA. First report of a tospovirus in a commercial crop of cape gooseberry in Brazil. New Dis Rep. 2012; https://doi.org/10.5197/j.2044-0588. 2012.025.025.

46. Webster CG, Perry KL, Lu X, Hosman L, Frantz G, Mellinger C, Adkins S. First report of Groundnut ringspot virus infecting tomato in South Florida. Plant Health Prog. 2010; https://doi.org/10.1094/PHP-2010-0707-01-BR.

47. Webster CG, Jensen CE, Rivera-Vargas LI, Rodrigues JCV, Frantz G, Mellinge HC, Adkins S. First report of Tomato chlorotic spot virus (TCSV) in tomato, pepper, and jimsonweed in Puerto Rico. Plant Health Prog. 2013; https://doi. org/10.1094/PHP-2013-0812-01-BR.

48. Webster CG, Frantz G, Reitz SR, Funderburk JE, Mellinger HC, McAvoy E, Turechek WW, Marshall SH, Tantiwanich Y, McGrath MT, Daughtrey ML, Adkins S. Emergence of Groundnut ringspot virus and Tomato chlorotic spot virus in vegetables in Florida and the southeastern United States. Phytopathology. 2015;105:388-98.

49. Adegbola RO, Fulmer AM, Williams B, Brenneman TB, Kemerait RC, Sheard W, Woodward JE, Adkins S, Naidu RA. First report of the natural occurrence of Tomato chlorotic spot virus in peanuts in Haiti. Plant Dis. 2016; https://doi. org/10.1094/PDIS-01-16-0070-PDN.

50. USDA, Plant protection and quarantine: helping U.S. agriculture thrive-across the country and around the world. In: annual report. United States Department of Agriculture. 2016. https://www.aphis.usda.gov/ publications/plant_health/report-ppq-2016.pdf. Accessed 20 July 2017.

51. Pimentel D. Plant pathogens and quarantines and the implication for global trade and world food. In: Loebenstein G, Thottappilly G, editors. Virus and virus-like diseases of major crops in developing countries. Dordrecht: Kluwer Academic; 2003. p. 79-89.

52. Patoka J, Bláha M, Kalous L, Vrabec V, Buřič M, Kouba A. Potential pest transfer mediated by international ornamental plant trade. Sci Rep. 2016;6:25896.

\section{Submit your next manuscript to BioMed Central and we will help you at every step:}

- We accept pre-submission inquiries

- Our selector tool helps you to find the most relevant journal

- We provide round the clock customer support

- Convenient online submission

- Thorough peer review

- Inclusion in PubMed and all major indexing services

- Maximum visibility for your research

Submit your manuscript at www.biomedcentral.com/submit

) Biomed Central 